\title{
New developments in acne treatment: role of combination adapalene-benzoylperoxide
}

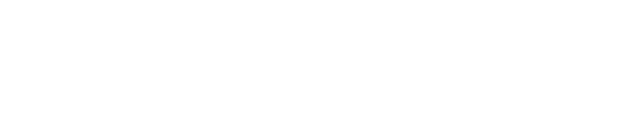

\section{Su Youn Kim \\ Falk R Ochsendorf \\ Clinic for Dermatology, Venereology, and Allergology, University Hospital, Frankfurt/M, Germany}

\begin{abstract}
The fixed-dose combination adapalene $0.1 \%$ /benzoylperoxide $2.5 \%(\mathrm{~A} / \mathrm{BPO})$ was introduced as an acne vulgaris therapeutic in 2007. It combines anti-inflammatory, keratolytic, comedolytic, and antibacterial properties. Thus, it addresses several pathophysiological factors involved in the pathophysiology of acne. This review highlights the rationale for the use of this fixed-dose combination product, its therapeutic efficacy including effects on adherence and quality of life, its use for different forms of acne, and the side-effect profile. In summary, the fixed-dose combination of A/BPO gel can be regarded as a highly effective and safe formulation. It is not associated with antibiotic resistance. It reduces factors that cause nonadherence and has positive effects on the quality of life of affected patients. The tolerance is good. The initial mild irritation potential can be addressed by adequate counseling. A/BPO can be used for all forms of inflammatory acne, including severe forms, as part of a combination with systemic antibiotics. Finally, it can also be used for the long-term treatment of chronic acne. Thus, it is a very valuable therapeutic option in daily practice, which is reflected by its strong recommendation in the "European S3-guidelines".
\end{abstract}

Keywords: adapalene, benzoylperoxide, acne vulgaris, treatment

\section{Management issues in the treatment of acne}

Acne vulgaris ranks number 8 in the list of the most common diseases worldwide. ${ }^{1}$ Acne is the main reason for visiting a dermatologist. ${ }^{2,3}$ Four relevant pathophysiological factors are involved: increased production of sebum, follicular hyperkeratinization, microbial colonization with Propionibacterium acnes, and inflammation. ${ }^{3}$ The relative contribution of each of these factors is under discussion. At present, inflammation is regarded as the most relevant factor in acne pathophysiology. Acne is clinically characterized by comedones, papules, pustules, and nodules (also known as cysts). These inflammatory lesions lead to scarring. ${ }^{4-6}$

Acne vulgaris strongly impacts the quality of life (QoL) of affected individuals. ${ }^{7}$ As there is no correlation between subjective and objective acne severity, even mildto-moderate acne can be associated with significant comorbidities such as depression and suicidal ideation. Therefore, the treating dermatologist must be aware of these psychosomatic aspects. ${ }^{8}$

Acne can be regarded as a chronic disease. ${ }^{9}$ Its duration varies from 3 months to 40 years. In many patients, acne does not spontaneously regress before the end of the twenties and may last much longer. ${ }^{10}$ Therefore, effective and safe long-term treatments are needed. Therapeutic success is impaired by lack of adherence. Poor adherence was evident in $40 \%-50 \%$ of treated acne patients. ${ }^{11}$ Therefore, therapies and methods that improve adherence should be preferred.
Correspondence: Falk R Ochsendorf Clinic for Dermatology, Venereology, and Allergology, University Hospital, Theodor-Stern-Kai 7, Frankfurt/M 60590, Germany

Tel +496963016661

Fax +496963015117

Email ochsendorf@em.uni-frankfurt.de 
In the management of acne, therapy of active acne aims to minimize visible disfiguration and to prevent scarring. After clinical improvement, maintenance therapy is necessary to prevent relapses and to sustain the achieved improvement. ${ }^{12,13}$ These therapies have to be effective, safe, well tolerated, and accepted by the patients. Nowadays, different kinds of effective therapeutic regimens for acne vulgaris are readily available. At present, the "European S3-guidelines", which discusses the different therapeutic approaches under evidence-based criteria, is being updated. ${ }^{14}$ The adequate use of these medications results in efficient disease management in most cases. However, low levels of acne knowledge and poor adherence to treatment recommendations impair therapeutic success and increase the risk for scarring. ${ }^{6,15}$ The aim of this paper, therefore, is to review the role of the fixed-dose combination of adapalene $0.1 \%$ /benzoylperoxide $2.5 \%$ (A/BPO), one of the most frequently prescribed topical treatments of acne vulgaris, in comparison to other topical agents.

\section{Current treatments for acne}

Acne vulgaris can be treated with topical agents (monotherapy or combination therapies: retinoids, benzoylperoxide [BPO], azelaic acid, antibiotics, and dapsone) and/or systemic drugs (antibiotics, zinc, antiandrogens, and isotretinoin). An S3-guideline as well as consensus statements by experts may guide individual choices for a given patient. ${ }^{9,14,16,17}$ This choice depends on the clinical severity, prior treatments, and individual patient preferences.

Topical retinoids, also known as vitamin A derivatives, are essential topical agents to treat acne. These utilize three active agents: tretinoin, tazarotene, and adapalene. Through binding to different sets of retinoic acid receptors, each of the three retinoids shows slight differences in efficacy and tolerability. They modulate gene transactivation and gene expression in human keratinocytes and unfold their anticomedogenic, anti-inflammatory, and immunomodulatory effects. ${ }^{18}$ However, the use of topical retinoids is limited by cutaneous side effects such as dryness, peeling, erythema, and irritation. ${ }^{12,18}$ Out of the aforementioned three retinoids, adapalene is the least irritating substance. ${ }^{14}$ Tretinoin was combined with the topical antibiotic clindamycin as a fixed combination reducing the irritation potential and increasing therapeutic efficacy. ${ }^{19}$

Another base therapeutic is BPO. It has a bactericidal activity against $P$. acnes. ${ }^{17}$ Different from antibiotics, there has been no report of resistance to BPO. ${ }^{17}$ Combined with a topical retinoid or a topical antibiotic, it can furthermore reduce the development of resistance as well as improve therapeutic results. ${ }^{17} \mathrm{BPO}$ is available in strengths ranging from $2.5 \%$ to $10 \%$ and can be used as leave-on or wash-off agents. Its use is limited by concentration-dependent cutaneous irritation. ${ }^{17}$ Fixed-combination agents are available with erythromycin 3\%/BPO 5\%, clindamycin 1\%/BPO 5\%, and clindamycin $1 \%$ /BPO $3.75 \%$, with the aim to reduce the emergence of resistance. ${ }^{20}$

Azelaic acid has antimicrobial effects as well as keratolytic properties. ${ }^{21}$ Moreover, it has comedolytic and anti-inflammatory effects. ${ }^{21}$ This agent is especially suited for patients with sensitive skin or dark skin type, ie, Fitzpatrick skin type IV, because of the lightening effect of dyspigmentation. ${ }^{17}$ A recent randomized, assessor-blinded, multicenter study has, however, demonstrated this agent to be less effective than a combination of clindamycin and $\mathrm{BPO} .^{21}$

Dapsone, a sulfone agent, as $5 \%$ gel is suggested to have a modest-to-moderate effect on acne. ${ }^{17}$ Salicylic acid $(0.5 \%-2 \%)$ is a comedolytic agent with limited data for efficacy. ${ }^{17}$

Antibiotics were widely used for acne over the past decades, mainly erythromycin and clindamycin as topical as well as cyclines and erythromycin as systemic antibiotics. As they have a low irritation potential and do not stain clothes, they did not need much explanation when prescribing.

The proliferation of $P$. acnes, an anaerobic Grampositive bacterium, was thought to play a pivotal role in acne-associated inflammation. The excess sebum production and abnormal desquamation of the follicular epithelium lead to the development of microcomedones and allow for an abnormal proliferation of $P$. acnes that is normally present in the skin of all individuals. ${ }^{22}$ In recent years, the ability of $P$. acnes to form biofilms, or the fact that certain phylogenetic strains could be associated with acne, modified the view on $P$. acnes as a relevant agent for the pathophysiology of acne vulgaris. ${ }^{23}$ The fact that $P$. acnes can trigger the secretion of proinflammatory cytokines such as interleukin- $1 \alpha$, interleukin- 8 , and tumor necrosis factor- $\alpha$ by keratinocytes through activating TLR2 is regarded as most relevant. ${ }^{6,22,24}$ Therefore, not only the antibiotic but also the anti-inflammatory properties of antibiotics appear to be responsible for therapeutic success. ${ }^{25}$

The extensive and wide use of antibiotics in the treatment of bacterial infections and acne has led to the development of resistance to antimicrobial therapy by many pathogens, including $P$. acnes, in the past few years. ${ }^{26}$ The incidence of $P$. acnes resistance to erythromycin increased from $0 \%$ in 1976 to $20 \%$ in 1978 and to $62 \%$ in $1996 .{ }^{27}$ 
It has been reported that over $50 \%$ of $P$. acnes strains are resistant, especially to topical macrolides in all major regions of the world. ${ }^{27}$ Therefore, all actual guidelines strongly advocate limiting the use of antibiotics and avoiding a topical antibiotic monotherapy. ${ }^{12,14,17}$ Especially for a chronic disease such as acne, long-term antibiotic therapies are not an option.

\section{Adapalene-BPO fixed combination in the treatment of acne}

To treat acne effectively, as many pathophysiological factors as possible should be addressed. Therefore, it is recommended to combine compounds with different modes of action in one preparation.

Adapalene, a naphtoic acid derivate, is a third-generation retinoid with anti-inflammatory, comedolytic, and anticomedogenic properties. ${ }^{28}$ It reduces the number of inflammatory lesions as well as comedones by reversing the process of abnormal follicular keratinization and inhibiting microcomedo formation. ${ }^{28}$ This agent is less likely to cause cutaneous side effects and is better tolerated than other retinoids. ${ }^{18,29}$ Moreover, it has been shown to block the early inflammatory reactions around the pilosebaceous follicle by modulating the expression of TLR $2 .{ }^{30}$ Adapalene also downregulates the cell surface receptor used by $P$. acnes for the release of proinflammatory cytokines. ${ }^{12,31}$ Because of its good tolerability profile and anti-inflammatory characteristics, adapalene is strongly recommended over first-generation retinoids, such as tretinoin and isotretinoin, in the treatment of acne.

As already mentioned, BPO is a safe and effective antimicrobial agent with comedolytic properties that shows a potent and rapid bactericidal effect against $P$. acnes without any evidence of antimicrobial resistance. ${ }^{6,28}$ It is more effective and acts faster than topical antibiotics against $P$. acnes. ${ }^{32,33}$ In addition, it is also known to have effects on yeasts. ${ }^{28}$ It has been demonstrated that there is no difference between $2.5 \%$ and $5 \%$ BPO with respect to antibacterial effects; however, higher concentrations are much more irritating. ${ }^{34,35}$ Therefore, the use of $2.5 \%$ BPO with low irritation potential is reasonable.

The combination of retinoids and antimicrobials is complementary and targets three of the four pathophysiological factors of acne. Furthermore, adapalene enhances the penetration of BPO by altering the follicular microclimate. ${ }^{36}$ Thus, from a theoretical point of view, the fixed combination of adapalene and BPO should be more effective than the monosubstances.

Numerous clinical trials have been conducted to test the efficacy of the topical treatment with a fixed-dose combination A/BPO gel in comparison to the monosubstances and the vehicle (Table 1).

Table I RCT comparing A/BPO fixed-dose combination gel to the monosubstances

\begin{tabular}{|c|c|c|c|c|c|}
\hline Study & Type of study & $\begin{array}{l}\text { Interventions } \\
\text { (duration) }\end{array}$ & Total (n) & $\begin{array}{l}\text { Summary of } \\
\text { efficacy }\end{array}$ & $\begin{array}{l}\text { Grade of } \\
\text { evidence }\end{array}$ \\
\hline \multicolumn{6}{|c|}{ Monotherapy with A/BPO combination gel } \\
\hline Thiboutot et $\mathrm{a}^{28}$ & $\begin{array}{l}\text { Multicenter, randomized, } \\
\text { double-blind }\end{array}$ & $\begin{array}{l}\text { I. A/BPO } \\
\text { 2. Adapalene monotherapy } \\
\text { 3. BPO monotherapy or } \\
\text { 4. Gel vehicle } \\
\text { ( } 12 \text { weeks, once daily) }\end{array}$ & 517 & $\begin{array}{l}\mathrm{A} / \mathrm{BPO}>\text { adapalene }> \\
\mathrm{BPO}>\text { vehicle }\end{array}$ & A \\
\hline Gold et al ${ }^{50}$ & $\begin{array}{l}\text { Multicenter, randomized, } \\
\text { double-blind }\end{array}$ & $\begin{array}{l}\text { I. A/BPO } \\
\text { 2. Adapalene monotherapy } \\
\text { 3. BPO monotherapy } \\
\text { 4. Gel vehicle } \\
\text { ( } 12 \text { weeks, once daily) }\end{array}$ & 1,668 & $\begin{array}{l}\mathrm{A} / \mathrm{BPO}>\text { adapalene } \approx \\
\mathrm{BPO}>\text { vehicle }\end{array}$ & A \\
\hline Gollnick et $\mathrm{al}^{51}$ & $\begin{array}{l}\text { Multicenter, randomized, } \\
\text { double-blind }\end{array}$ & $\begin{array}{l}\text { I. A/BPO } \\
\text { 2. Adapalene monotherapy } \\
\text { 3. BPO monotherapy } \\
\text { 4. Gel vehicle } \\
\text { (I2 weeks, once daily) }\end{array}$ & 1,670 & $\begin{array}{l}\mathrm{A} / \mathrm{BPO}>\mathrm{BPO}> \\
\text { adapalene }>\text { vehicle }\end{array}$ & A \\
\hline Eichenfield et $\mathrm{al}^{39}$ & $\begin{array}{l}\text { Multicenter, randomized, } \\
\text { vehicle-controlled, double-blind } \\
\text { clinical trials in preadolescents }\end{array}$ & $\begin{array}{l}\text { I. A/BPO } \\
\text { 2. Vehicle } \\
\text { (12 weeks, once daily) }\end{array}$ & 285 & $\mathrm{~A} / \mathrm{BPO}>$ vehicle & A \\
\hline
\end{tabular}

Notes: Grade of evidence: A = randomized, double-blind clinical trial of high quality (eg, sample-size calculation, flow chart of patient inclusion, intention-to-treat [ITT] analysis, sufficient sample size). $\mathrm{B}=$ randomized clinical trial of lesser quality (eg, only single-blind, no ITT). C = comparative trial with severe methodological limitations (eg, not blinded, very small sample size). Adapted from Nast A, Dréno B, Bettoli V, et al. European evidence-based (S3) guidelines for the treatment of acne - update 2016 - short version. J Eur Acad Dermatol Venereol. 2016;30:126I-1268, ${ }^{14}$ with permission from John Wiley and Sons.

Abbreviations: RCT, randomized controlled trials; A/BPO, adapalene $0.1 \% /$ benzoylperoxide $2.5 \%$; BPO, benzoylperoxide $2.5 \%$. 
Eichenfield et $\mathrm{al}^{37}$ summarized the efficacy of the A/BPO combination gel, demonstrated in three randomized, multicenter, double-blind, active- and vehicle-controlled studies. These studies included 2,453 acne patients between the ages of 12 and 17. A total of 619 patients received a fixed-dose A/BPO combination gel, 636 received an adapalene monotherapy, 633 received a BPO monotherapy, and 565 received a gel vehicle. After 12 weeks of treatment, a superior efficacy of $\mathrm{A} / \mathrm{BPO}$ compared to the vehicle was found (range of reduction in inflammatory lesions of A/BPO: $62.1 \%-70.3 \%$, for vehicle: $14.3 \%-45.5 \%$, Level of evidence: 1 [further research is very unlikely to change the confidence in the estimated effect]).

$\mathrm{A} / \mathrm{BPO}$ was also more effective than adapalene (range of reduction in inflammatory lesions: $46 \%-57.1 \%$, Level of evidence: 1). For BPO, the reduction of inflammatory lesions ranged from $44 \%$ to $71.8 \%$; in two studies this effect was comparable to the combination; in one study A/BPO had a superior effect (Table 1). Furthermore, a significantly greater reduction in total inflammatory and noninflammatory lesion counts could be seen in the A/BPO-group as early as week 2 , while an onset of action in all other groups was observed at the earliest at week 4 (BPO-group). ${ }^{37}$

Another analysis of the data from these three randomized controlled studies demonstrated the synergistic efficacy of the A/BPO combination gel. The benefit of the fixed-dose
$\mathrm{A} / \mathrm{BPO}$ combination was greater than the sum of benefits of adapalene and BPO monotherapies in reducing the inflammatory and noninflammatory lesion count. ${ }^{38}$

Also in preadolescents ( $9-11$ years old), the A/BPO fixed combination showed a superior efficacy compared to the vehicle (reduction in both inflammatory and noninflammatory lesions $68.6 \%$ vs $19.3 \%$ with vehicle). ${ }^{39}$

Acne vulgaris is a chronic disease with a high relapse rate. Even after successful treatment, the maintenance of the achieved improvement is not easy. The relapse rate after successful therapy, however, ranges from $14.6 \%$ to $52 \%$. Multiple studies on the long-term efficacy of A/BPO combination gel showed that this fixed-dose combination gel is both very effective in preventing recurrence and is safe in long-term use, ie, over 6 to 12 months (Table 2). Interestingly, one of the studies revealed that the additional daily application of topical clindamycin for 8 weeks in patients who experienced a relapse of acne despite $\mathrm{A} / \mathrm{BPO}$ combination therapy resulted in complete acne remission. ${ }^{40}$

In a direct comparison, $\mathrm{A} / \mathrm{BPO}$ was as effective as clindamycin/BPO (Table 3). The latter, however, showed a better tolerability.

In the treatment of severe acne vulgaris, A/BPO combination gel can be combined with oral antibiotics such as doxycycline $(100 \mathrm{mg} / \mathrm{d})$. This was significantly more effective than the combination with a vehicle (Table 4). Tan et $\mathrm{al}^{38}$

Table 2 Results of long-term studies with A/BPO fixed-dose combination gel

\begin{tabular}{|c|c|c|c|c|c|}
\hline Study & Type of study & Interventions (duration) & Total (n) & Summary of efficacy & $\begin{array}{l}\text { Grade of } \\
\text { evidence }\end{array}$ \\
\hline Pariser et $\mathrm{al}^{|3|}$ & Multicenter, open-label, single-arm & $\begin{array}{l}\text { A/BPO } \\
\text { (12 months, once daily) }\end{array}$ & 452 & $\begin{array}{l}\text { Significant reduction of total } \\
\text { lesion count. No subject } \\
\text { discontinued because of lack } \\
\text { of efficacy }\end{array}$ & B \\
\hline Poulin et al ${ }^{13}$ & $\begin{array}{l}\text { Multicenter, double-blind, } \\
\text { randomized, controlled }\end{array}$ & $\begin{array}{l}\text { I. A/BPO } \\
\text { 2. Vehicle } \\
(6 \text { months, once daily) }\end{array}$ & 243 & $\begin{array}{l}\text { Significantly higher lesion } \\
\text { maintenance success rate in } \\
\text { A/BPO side. A/BPO prevents } \\
\text { the occurrence of relapse }\end{array}$ & A \\
\hline Betolli et a $\left.\right|^{40}$ & $\begin{array}{l}\text { Single-center, open-label, } \\
\text { prospective-cohort, noncomparative } \\
\text { study consisting of two phases } \\
\text { (active treatment phase and a } \\
\text { maintenance phase) }\end{array}$ & $\begin{array}{l}\text { A/BPO } \\
\text { (after a successful acne therapy } \\
\text { with oral isotretinoin for } \\
12 \text { months, once daily) }\end{array}$ & 69 & $\begin{array}{l}\text { Relapse of acne under } \\
\text { A/BPO was } 2.94 \%\end{array}$ & C \\
\hline Gollnick et $\mathrm{a}^{6}$ & $\begin{array}{l}\text { Multicenter, open-label, prospective } \\
\text { noninterventional, observational } \\
\text { cohort study }\end{array}$ & $\begin{array}{l}\text { A/BPO ( } 78.8 \%) \text { monotherapy or } \\
\text { A/BPO ( } 21.2 \%) \text { in combination } \\
\text { with other drugs ( } 8.8 \% \text { topicals, } \\
8.7 \% \text { systemic antibiotics) } \\
\text { ( } 9 \text { months, once daily) }\end{array}$ & $5,13 \mid$ & $\begin{array}{l}\text { No more visible acne lesions } \\
\text { after applying A/BPO for a } \\
\text { median time of } 3 \text { months in } \\
8.2 \% \text { of the subjects, after } \\
9 \text { months in } 25.8 \%\end{array}$ & C \\
\hline
\end{tabular}

Notes: Grade of evidence: $\mathrm{A}=$ randomized, double-blind clinical trial of high quality (eg, sample-size calculation, flow chart of patient inclusion, intention-to-treat [ITT] analysis, sufficient sample size). B = randomized clinical trial of lesser quality (eg, only single-blind, no ITT). C = comparative trial with severe methodological limitations (eg, not blinded, very small sample size). Adapted from Nast A, Dréno B, Bettoli V, et al. European evidence-based (S3) guidelines for the treatment of acne - update 2016 short version. J Eur Acad Dermatol Venereol. 2016;30:126I-1268, ${ }^{14}$ with permission from John Wiley and Sons. Abbreviation: A/BPO, adapalene $0.1 \%$ /benzoylperoxide $2.5 \%$. 
Table 3 Comparison of topical A/BPO with topical clindamycin/BPO

\begin{tabular}{|c|c|c|c|c|c|}
\hline Study & $\begin{array}{l}\text { Type of } \\
\text { study }\end{array}$ & $\begin{array}{l}\text { Interventions } \\
\text { (duration) }\end{array}$ & Total (n) & Summary of efficacy & $\begin{array}{l}\text { Grade of } \\
\text { evidence }\end{array}$ \\
\hline $\begin{array}{l}\text { Zouboulis } \\
\text { et } \mathrm{al}^{52}\end{array}$ & $\begin{array}{l}\text { Multicenter, } \\
\text { randomized, } \\
\text { controlled trial }\end{array}$ & $\begin{array}{l}\text { I. A/BPO } \\
\text { 2. Clindamycin/BPO } \\
\text { (I2 weeks, once daily) }\end{array}$ & 382 & $\mathrm{~A} / \mathrm{BPO}=$ clindamycin $/ \mathrm{BPO}$ & B \\
\hline $\begin{array}{l}\text { Gonzalez } \\
\text { et } \mathrm{al}^{53}\end{array}$ & Split face & $\begin{array}{l}\text { I. A/BPO } \\
\text { 2. Clindamycin/BPO } \\
\text { ( } 2 \text { weeks, once daily) }\end{array}$ & 48 & $\mathrm{~A} / \mathrm{BPO}=$ clindamycin/BPO & $\mathrm{C}$ \\
\hline
\end{tabular}

Notes: Grade of evidence: $A$ = randomized, double-blind clinical trial of high quality (eg, sample-size calculation, flow chart of patient inclusion, intention-to-treat [ITT] analysis, sufficient sample size). B = randomized clinical trial of lesser quality (eg, only single-blind, no ITT). C = comparative trial with severe methodological limitations (eg, not blinded, very small sample size). Adapted from Nast A, Dréno B, Bettoli V, et al. European evidence-based (S3) guidelines for the treatment of acne - update 2016 short version. J Eur Acad Dermatol Venereol. 2016;30:126I-1268, ${ }^{14}$ with permission from John Wiley and Sons.

Abbreviations: A/BPO, adapalene $0.1 \% /$ benzoylperoxide $2.5 \%$; BPO, benzoylperoxide $2.5 \%$.

demonstrated in a randomized, vehicle-controlled, multicenter, double-blind study that this combination was even as effective as oral isotretinoin in severe acne vulgaris. ${ }^{41}$

\section{Safety and tolerability}

Good tolerability is a significant factor for successful acne treatment. Topical agents that are well tolerated and show a quick onset of action may help improve the therapy outcomes by preventing discontinuation or intermittent application of topical medications. ${ }^{42}$ Topical agents mainly have local side effects such as stinging/burning, dryness, scaling, and erythema. This may lead to poor treatment outcomes because of nonadherence to topical therapies. ${ }^{42}$

Several studies investigated the safety and tolerability of the fixed-dose combination of A/BPO gel. In Table 5, trials that assessed the safety and tolerability of this agent at time points between 1 week and 12 months are summarized.

In a large observational study with more than 5,100 patients, $90 \%$ of the patients identified tolerability as being good or very good. ${ }^{43}$ However, about every second patient had at least one local skin irritation (dryness: $30.7 \%$, erythema: $24.3 \%$, desquamation: $22.4 \%$ ). Most irritations $(71.7 \%)$ were mild and resolved after discontinuation. Only $1.7 \%$ of patients stopped application because of these irritable side effects. In general, patients with lower acne severity grade tolerated the topical fixed-dose combination better. ${ }^{6}$ In Figure 1, the time course of the most common adverse drug reaction, dry skin, is illustrated. As can be seen, the highest scores occurred in week 1 and returned to baseline values at week 12. This has to be taken into account when counseling the patients (see "Patient factors"). Suspected allergic reactions to $\mathrm{BPO}$ were rare $(0.1 \%)$.

To improve the tolerability of $\mathrm{A} / \mathrm{BPO}$ gel, different methods have been suggested in some clinical trials. For instance, Rueda ${ }^{44}$ showed in a 15-day open-label study that the safety and tolerability of A/BPO gel can be increased by using a more consistent amount of $\mathrm{A} / \mathrm{BPO}$ gel dispensed from a pump. The use of a pump system reduced the occurrence of

Table 4 Combination therapy of A/BPO fixed-dose combination gel with systemic agents

\begin{tabular}{|c|c|c|c|c|c|}
\hline Study & Type of studies & $\begin{array}{l}\text { Interventions } \\
\text { (duration) }\end{array}$ & Total (n) & Summary of efficacy & $\begin{array}{l}\text { Grade of } \\
\text { evidence }\end{array}$ \\
\hline Gold et $\mathrm{al}^{41}$ & $\begin{array}{l}\text { Randomized, vehicle- } \\
\text { controlled, multicenter, } \\
\text { double-blind }\end{array}$ & $\begin{array}{l}\text { Doxycycline hyclate } 100 \mathrm{mg} \text { with either } \\
\text { I. A/BPO or } \\
\text { 2. Vehicle } \\
\text { (I2 weeks, once daily) }\end{array}$ & 459 & $\begin{array}{l}\text { Doxycycline hyclate } 100 \mathrm{mg}+ \\
\text { A/BPO > doxycycline hyclate } \\
100 \mathrm{mg}+\text { vehicle }\end{array}$ & A \\
\hline Dréno et $\mathrm{al}^{46}$ & $\begin{array}{l}\text { Randomized, double-blind, } \\
\text { controlled }\end{array}$ & $\begin{array}{l}\text { Lymecycline } 300 \mathrm{mg} \text { with either } \\
\text { I. A/BPO or } \\
\text { 2. Vehicle } \\
\text { (I2 weeks, once daily) }\end{array}$ & 378 & $\begin{array}{l}\text { Lymecycline } 300 \mathrm{mg}+\mathrm{A} / \mathrm{BPO}> \\
\text { lymecycline } 300 \mathrm{mg}+\text { vehicle }\end{array}$ & A \\
\hline Tan et $\mathrm{al}^{54}$ & $\begin{array}{l}\text { Multicenter, randomized, } \\
\text { controlled, noninferiority } \\
\text { investigator-blinded }\end{array}$ & $\begin{array}{l}\text { 1. Doxycycline hyclate } 200 \mathrm{mg} \text { with } \\
\text { A/BPO or } \\
\text { 2. Oral isotretinoin }(0.5-1.0 \mathrm{mg} / \mathrm{kg}) \\
\text { ( } 20 \text { weeks, once daily) }\end{array}$ & 266 & $\begin{array}{l}\text { Doxycycline hyclate } 200 \mathrm{mg} \\
\text { with } \mathrm{A} / \mathrm{BPO}=\text { oral isotretinoin }\end{array}$ & B \\
\hline
\end{tabular}

Notes: Grade of evidence: A = randomized, double-blind clinical trial of high quality (eg, sample-size calculation, flow chart of patient inclusion, intention-to-treat [ITT] analysis, sufficient sample size). $\mathrm{B}=$ randomized clinical trial of lesser quality (eg, only single-blind, no ITT). C = comparative trial with severe methodological limitations (eg, not blinded, very small sample size). Adapted from Nast A, Dréno B, Bettoli V, et al. European evidence-based (S3) guidelines for the treatment of acne - update 2016 - short version. J Eur Acad Dermatol Venereol. 2016;30:126I-1268, ${ }^{14}$ with permission from John Wiley and Sons.

Abbreviation: A/BPO, adapalene $0.1 \%$ /benzoylperoxide $2.5 \%$. 
Table 5 Summary of safety and tolerability profile of studies with A/BPO fixed-dose combination gel

\begin{tabular}{|c|c|c|c|c|c|c|}
\hline Study & Type of study & $\begin{array}{l}\text { Interventions } \\
\text { (duration) }\end{array}$ & Total (n) & $\begin{array}{l}\text { Summary of } \\
\text { dermatological ADR }\end{array}$ & $\begin{array}{l}\text { Summary of safety } \\
\text { and tolerability }\end{array}$ & $\begin{array}{l}\text { Grade of } \\
\text { evidence }\end{array}$ \\
\hline $\begin{array}{l}\text { Thiboutot } \\
\text { et } \mathrm{al}^{28}\end{array}$ & $\begin{array}{l}\text { Multicenter, } \\
\text { randomized, } \\
\text { double-blind, } \\
\text { controlled studies }\end{array}$ & $\begin{array}{l}\text { A/BPO vs adapalene vs } \\
\text { BPO vs vehicle } \\
\text { ( } 12 \text { weeks, once daily) }\end{array}$ & 517 & $\begin{array}{l}\text { Incidence of treatment-related } \\
\text { adverse events: } \\
\text { A/BPO: } 17.4 \% \\
\text { Adapalene: } 20.3 \% \\
\text { BPO: } 6.7 \% \\
\text { Vehicle: } 5.6 \% \\
\text { Most frequent: dry skin } \\
\text { A/BPO: } 9.4 \% \\
\text { Adapalene: } 10.1 \% \\
\text { BPO: } 2.0 \% \\
\text { Vehicle: } 1.4 \%\end{array}$ & $\mathrm{~A} / \mathrm{BPO} \approx$ adapalene & A \\
\hline $\begin{array}{l}\text { Pariser } \\
\text { et } \mathrm{al}^{|3|}\end{array}$ & $\begin{array}{l}\text { Multicenter, open- } \\
\text { label, single-arm } \\
\text { study }\end{array}$ & $\begin{array}{l}\text { Evaluation of safety and } \\
\text { efficacy of adapalene/BPO } \\
\text { ( } 12 \text { months, once daily) }\end{array}$ & 452 & $\begin{array}{l}\text { Incidence of treatment-related } \\
\text { adverse events: } 32.5 \% \\
\text { Most frequent: dry skin (I7.3\%) }\end{array}$ & $\begin{array}{l}\text { Safe and effective use of } \\
\text { A/BPO up to } 12 \text { months }\end{array}$ & C \\
\hline $\begin{array}{l}\text { Loesche } \\
\text { et } \mathrm{al}^{55}\end{array}$ & $\begin{array}{l}\text { Cumulative } \\
\text { irritancy study }\end{array}$ & $\begin{array}{l}\text { Comparison of cumulative } \\
\text { irritancy of adapalene/ } \\
\text { BPO to adapalene } 0.1 \% \\
\text { and BPO } 2.5 \% \text { applied } \\
\text { separately, BPO } 10 \% \text { gel, } \\
\text { tazarotene } 0.1 \% \text { gel, and } \\
\text { the gel vehicle }\end{array}$ & $\begin{array}{l}\text { Healthy } \\
\text { volunteers }\end{array}$ & & $\begin{array}{l}\text { Cumulative irritancy: } \\
\text { A/BPO = BPO: } 2.5 \%= \\
\text { BPO: } 10 \%=\text { adapalene: } \\
0.1 \%<\text { tazarotene: } 0.1 \%\end{array}$ & C \\
\hline $\begin{array}{l}\text { Gollnick } \\
\text { et } \mathrm{al}^{51}\end{array}$ & $\begin{array}{l}\text { Randomized, } \\
\text { double-blind, } \\
\text { controlled trial }\end{array}$ & $\begin{array}{l}\text { A/BPO vs adapalene vs } \\
\text { BPO vs vehicle ( } 12 \text { weeks, } \\
\text { once daily) }\end{array}$ & 1,670 & $\begin{array}{l}\text { Overall incidence of treatment- } \\
\text { related adverse events: } \\
\text { A/BPO: } 31 \% \\
\text { Adapalene: } 19 \% \\
\text { BPO: } 13 \% \\
\text { Most frequent: dry skin } \\
\text { A/BPO: } 21.2 \% \\
\text { Dapalene: } 14.1 \% \\
\text { BPO: } 8.4 \% \\
\text { Vehicle: } 5.3 \%\end{array}$ & $\begin{array}{l}\mathrm{A} / \mathrm{BPO} \approx \text { adapalene }> \\
\mathrm{BPO}>\text { vehicle }\end{array}$ & A \\
\hline $\begin{array}{l}\text { Zouboulis } \\
\text { et } \mathrm{al}^{52}\end{array}$ & $\begin{array}{l}\text { Multicenter, } \\
\text { randomized, } \\
\text { controlled trial }\end{array}$ & $\begin{array}{l}\text { A/BPO, clindamycin/BPO } \\
\text { (12 weeks, once daily) }\end{array}$ & 382 & $\begin{array}{l}\text { Clindamycin/BPO } 48.4 \% \text { ADR } \\
\text { ( } 3 \text { dropouts), A/BPO } 78.6 \% \\
\text { ADR ( } 9 \text { dropouts) }\end{array}$ & & B \\
\hline $\begin{array}{l}\text { Eichenfield } \\
\text { et } \mathrm{al}^{37}\end{array}$ & $\begin{array}{l}\text { Randomized, } \\
\text { multicenter, } \\
\text { double-blind, } \\
\text { active- and vehicle- } \\
\text { controlled studies }\end{array}$ & $\begin{array}{l}\text { Evaluation of efficacy } \\
\text { and safety of adapalene/ } \\
\text { BPO compared to those } \\
\text { of adapalene, BPO, and } \\
\text { the gel vehicle ( } 12 \text { weeks } \\
\text { once daily) }\end{array}$ & 2,425 & $\begin{array}{l}\text { Overall incidence of treatment- } \\
\text { related adverse events: } \\
\text { A/BPO: } 21.5 \% \\
\text { Adapalene: } 15.1 \% \\
\text { BPO: } 8.1 \% \\
\text { Vehicle: } 5.7 \% \\
\text { Most frequent: dry skin } \\
\text { A/BPO: } 13.4 \% \\
\text { Adapalene: } 9.6 \% \\
\text { BPO: } 3.9 \%\end{array}$ & $\begin{array}{l}\mathrm{A} / \mathrm{BPO} \approx \text { adapalene }> \\
\mathrm{BPO}>\text { vehicle }\end{array}$ & A \\
\hline $\begin{array}{l}\text { Green } \\
\text { et } \mathrm{al}^{56}\end{array}$ & Split-face & $\begin{array}{l}\text { A/BPO } \\
\text { Clindamycin/BPO } \\
\text { (2 weeks, once daily) }\end{array}$ & 72 & $\begin{array}{l}\text { Mean scores for erythema, } \\
\text { dryness, and peeling were } \\
\text { significantly higher with A/BPO } \\
\text { than with clindamycin/BPO. } \\
\text { Patients rated clindamycin/BPO } \\
\text { gel more tolerable than A/BPO }\end{array}$ & $\begin{array}{l}\text { A/BPO < clindamycin/ } \\
\text { BPO }\end{array}$ & C \\
\hline $\begin{array}{l}\text { Gollnick } \\
\text { et } \mathrm{al}^{6}\end{array}$ & $\begin{array}{l}\text { Multicenter, open- } \\
\text { label, prospective } \\
\text { noninterventional } \\
\text { observational } \\
\text { cohort study }\end{array}$ & $\begin{array}{l}\text { Evaluation of efficacy } \\
\text { and safety of adapelene/ } \\
\text { BPO in a real-world } \\
\text { noninterventional setting } \\
\text { ( } 9 \text { months, once daily) }\end{array}$ & $5,|3|$ & $\begin{array}{l}\text { Dryness: } 30.7 \% \\
\text { Erythema: } 24.3 \% \\
\text { Scaling: } 22.4 \%\end{array}$ & $\begin{array}{l}\text { Good safety and } \\
\text { tolerability }\end{array}$ & C \\
\hline
\end{tabular}


Table 5 (Continued)

\begin{tabular}{|c|c|c|c|c|c|c|}
\hline Study & Type of study & $\begin{array}{l}\text { Interventions } \\
\text { (duration) }\end{array}$ & Total (n) & $\begin{array}{l}\text { Summary of } \\
\text { dermatological ADR }\end{array}$ & $\begin{array}{l}\text { Summary of safety } \\
\text { and tolerability }\end{array}$ & $\begin{array}{l}\text { Grade of } \\
\text { evidence }\end{array}$ \\
\hline $\begin{array}{l}\text { Kwon } \\
\text { et } \mathrm{al}^{45}\end{array}$ & $\begin{array}{l}\text { Single-blind, } \\
\text { controlled, split- } \\
\text { face trial }\end{array}$ & $\begin{array}{l}\text { Comparison of A/BPO } \\
\text { with BPO in terms of } \\
\text { efficacy and tolerability } \\
\text { in Korean population } \\
\text { ( } 12 \text { weeks, once daily) }\end{array}$ & 170 & $\begin{array}{l}\text { A/BPO: } \\
\text { Dry skin: } 53.3 \% \\
\text { Scaling: } 46.7 \% \\
\text { Erythema: } 40.0 \% \\
\text { Stinging or burning: } 40.0 \%\end{array}$ & $\begin{array}{l}\text { Frequency and intensity } \\
\text { of local irritation effects: } \\
\text { more severe in A/BPO- } \\
\text { treated sides, compared } \\
\text { with BPO sides }\end{array}$ & C \\
\hline $\begin{array}{l}\text { Sittart } \\
\text { et } \mathrm{al}^{57}\end{array}$ & $\begin{array}{l}\text { Multicenter, open- } \\
\text { label study }\end{array}$ & $\begin{array}{l}\text { Evaluation of the efficacy, } \\
\text { tolerability, and safety of } \\
\text { A/BPO in the Brazilian } \\
\text { population ( } 12 \text { weeks, } \\
\text { once daily) }\end{array}$ & 73 & $\begin{array}{l}\text { Erythema: week I: mild } 43.8 \% \text {, } \\
\text { moderate } 19.2 \% \text {, severe } 1.4 \% \text {. } \\
\text { Week I2: moderate } 4.1 \% \text {, } \\
\text { mild } 16.4 \% \text {. } \\
\text { Burning: week I: mild } 50.7 \% \text {, } \\
\text { moderate } 27.4 \% \text {, severe } 6.8 \% \text {. } \\
\text { Week I2: no burning } 80 \% \text {. } \\
\text { Dryness: week I: mild } 56.2 \% \text {, } \\
\text { moderate } 17.8 \% \text {, severe } 1.4 \% \\
\text { Scaling: week I: mild } 43.8 \% \text {, } \\
\text { moderate } 19.2 \% \text {, severe } 1.4 \%\end{array}$ & $\begin{array}{l}\text { Good safety and } \\
\text { tolerability }\end{array}$ & C \\
\hline
\end{tabular}

Notes: Grade of evidence: A = randomized, double-blind clinical trial of high quality (eg, sample-size calculation, flow chart of patient inclusion, intention-to-treat [ITT] analysis, sufficient sample size). $\mathrm{B}=$ randomized clinical trial of lesser quality (eg, only single-blind, no ITT). $\mathrm{C}=$ comparative trial with severe methodological limitations (eg, not blinded, very small sample size). Adapted from Nast A, Dréno B, Bettoli V, et al. European evidence-based (S3) guidelines for the treatment of acne - update 2016 short version. J Eur Acad Dermatol Venereol. 2016;30:126I-1268, ${ }^{14}$ with permission from John Wiley and Sons.

Abbreviations: $n$, number of participants; ADR, adverse drug reactions; A/BPO, adapalene $0.1 \% /$ benzoylperoxide $2.5 \%$; BPO, benzoylperoxide $2.5 \%$.
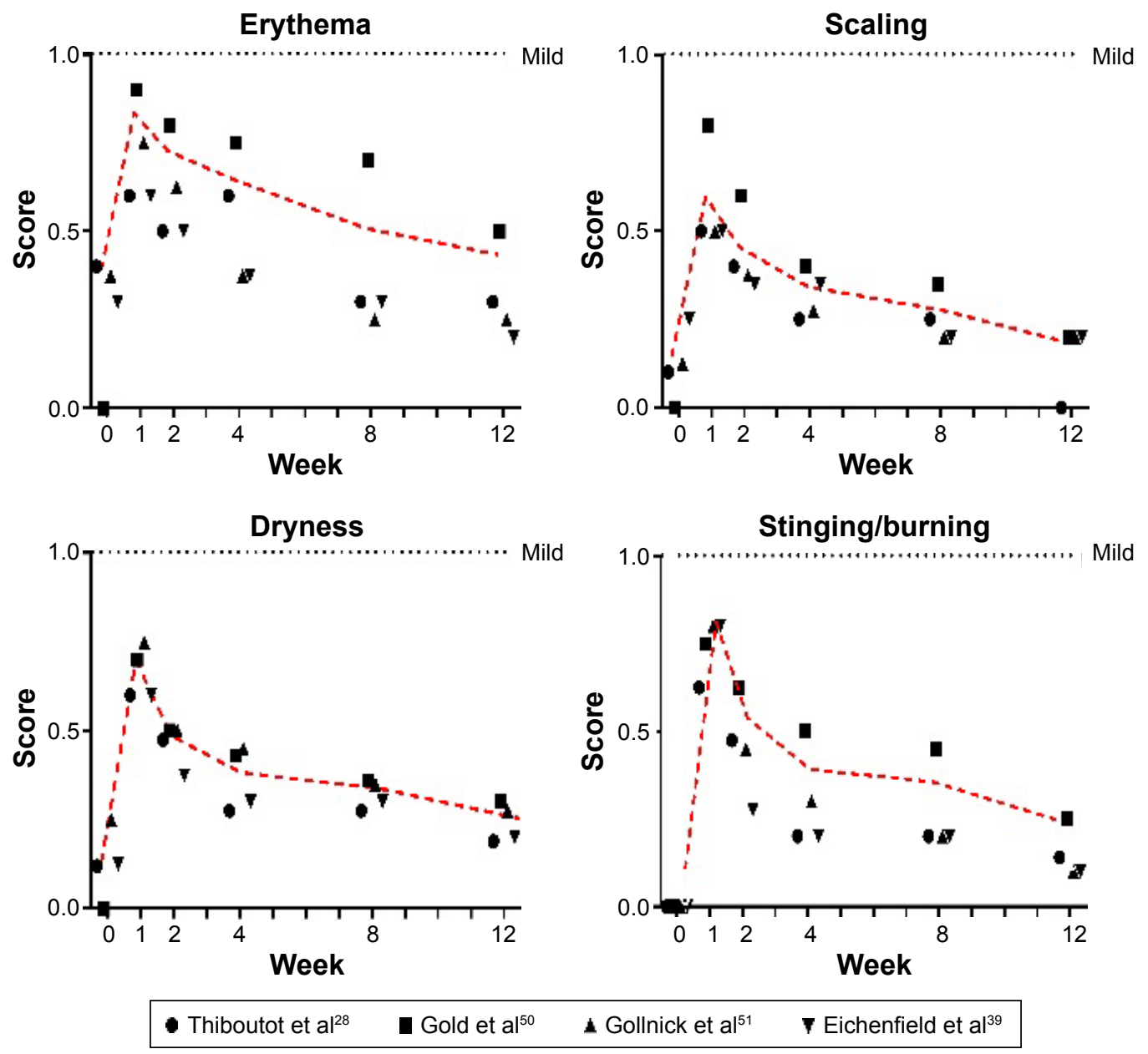

Figure I Time course of local side effects under A/BPO fixed combination gel.

Notes: The red dotted line illustrates the mean time course. The score denotes: $0=$ none, $I=$ mild, $2=$ moderate, $3=$ severe. 
cutaneous side effects by preventing overapplication of the gel. ${ }^{44}$ Furthermore, Kwon et $\mathrm{al}^{45}$ demonstrated a significant decrease in all local skin irritations (erythema, scaling, dryness, and stinging/burning) caused by A/BPO in the group of patients who received a dermatological application tutorial compared to the subjects without previous instruction on application techniques, underlying the importance of patient education in reducing side effects and increasing the tolerability of applied topical medications.

\section{Patient factors: QoL, satisfaction, and adherence}

Beneficial in vitro and in vivo effects of therapeutics as well as excellent results of well-controlled studies are useless if a therapy is not accepted or used by the patient. Poor adherence is assumed to be a major reason for treatment failure in acne vulgaris. ${ }^{46-48}$ In young adults and adolescent patients with acne, the adherence rates were reported to be approximately $50 \%{ }^{46,49}$ Anderson et $\mathrm{l}^{47}$ analyzed primary nonadherence of acne patients. On average, one in four patients (27\%) did not fill their prescriptions. The percentage increased from $9 \%$ if one agent was prescribed to $40 \%$ if two different agents were ordered. ${ }^{47}$ These results underline the importance of simple and convenient therapy regimens for a successful acne treatment. Patients prefer topical agents that can be applied by hand and only once daily, that can be kept at room temperature, that come as a gel, and that have a long shelf life. The fixed-dose combination of $\mathrm{A} / \mathrm{BPO}$ fulfills these preferences.

If therapy improves the skin condition rapidly, adherence increases, as the patient sees the advantage of the treatment. This correlation was confirmed in a recent large observational study. A low rate of side effects also improves adherence. ${ }^{6,12}$ $\mathrm{A} / \mathrm{BPO}$ has some irritation potential, especially in the first 2 weeks of treatment (Figure 1). The availability of a pump helps regulate use, which minimizes one possible reason for irritation. The pump applicator is well accepted by users. When prescribing this compound, the following recommendations may increase adherence:

1. Explain the application thoroughly: a "dermatological tutorial" increased tolerability without reducing success.

2. Recommend the use of a moisturizer: this improved adherence.

3. Inform the patient that the "burning sensation" is a sign that the therapy is working and will disappear after about 2 weeks.

4. On sensitive skin, start to use the A/BPO gel every other day until the burning/stinging sensation subsides $(\sim 2$ weeks) and then switch to a daily application.
With this approach, most patients will tolerate therapy and will benefit from it.

In order to determine the acceptance, adherence, tolerability, and effects on QoL under real-life conditions, field studies are very helpful. They reflect situations in real-world practice. In a prospective noninterventional observational study (2,780 patients, $12-20$ years old, moderate acne, 12-week use), the adherence of a topical A/BPO fixed combination was good in $63 \%$ of patients. ${ }^{6}$ Another prospective, noninterventional study $(5,131$ patients, moderate-to-severe acne, up to 9-month usage) showed good long-term adherence in $83.9 \%$ of patients. This study again showed that adherence had a significant positive effect on efficacy and QoL.

QoL can be assessed by different tools. It was clear that acne severely impaired QoL. Low QoL and lack of adherence were correlated and resulted in low efficacy. Thus, a therapy that can improve QoL will be more beneficial to patients. In severe acne, the fixed-dose combination A/BPO was able to improve QoL significantly, better than the vehicle after 12 weeks. There was a sustained improvement if treatment was continued, while in the vehicle arm QoL significantly worsened. In an observational study with A/BPO, QoL significantly improved after just 3 months and continued to improve until the end of the study ( 9 months). Hence, this gel is well suited for a long-term therapy, as it increases both QoL and adherence. In line with these findings is the fact that $82.3 \%-84.8 \%$ of patients were satisfied or very satisfied with this therapy under practice conditions.

\section{Conclusion}

The fixed-dose combination A/BPO reduces the complexity of acne treatment. Improvement of acne starts as early as 14 days. A/BPO improves treatment adherence and QoL. The compound is equally effective in both women and men of all ages. It can be used for mild to severe acne, in the latter form, as part of a combination therapy together with oral antibiotics. It can be used as a maintenance treatment for many months. In contrast to antibiotics, this compound has no risk of inducing antibiotic resistance, neither during short- nor during long-term use. Its side effect profile is comprised of local irritation, which can be minimized by adequate counseling. Thus, A/BPO is a valuable therapeutic option and received a strong recommendation for treatment of mild-to-moderate papulopustular facial acne in the "European S3-guidelines". For severe papulopustular/moderate nodular acne and severe nodular/conglobate acne, it received a medium strength recommendation as part of a combination therapy with systemic antibiotics. Therefore, A/BPO is a very valuable drug both 
in the induction as well as the maintenance therapy of nearly all forms of acne vulgaris.

\section{Acknowledgment}

We thank Chelsey Grimm for language editing.

\section{Disclosure}

Falk R Ochsendorf received honoraria for expert meetings with Galderma Laboratories, MEDA Pharma, GlaxoSmithKline Stiefel Pharma, Pierre-Fabre, Vichy Laboratories, as well as lecture fees during congresses/CME activities from Galderma Laboratories, MEDA Pharma, GlaxoSmithKline Stiefel Pharma. The authors report no other conflicts of interest in this work.

\section{References}

1. Hay RJ, Johns NE, Williams HC, et al. The global burden of skin disease in 2010: an analysis of the prevalence and impact of skin conditions. J Invest Dermatol. 2014;134(6):1527-1534.

2. Stern RS. Dermatologists and office-based care of dermatologic disease in the 21st century. J Investig Dermatol Symp Proc. 2004;9(2): $126-130$

3. Zouboulis CC. [Pathophysiology of acne. What is confirmed?]. Hautarzt. 2013;64(4):235-240. German.

4. Zouboulis CC, Katsambas AD, Kligman AM, editors. Pathogenesis and Treatment of Acne and Rosacea. Heidelberg, New York, Dordrecht, London: Springer; 2014.

5. Cunliffe WJ, Gollnick H. Acne Diagnosis and Management. London, UK: Martin Dunitz, Ltd; 2001.

6. Gollnick HP, Friedrich M, Peschen M, et al. Safety and efficacy of adapalene $0.1 \%$ /benzoyl peroxide $2.5 \%$ in the long-term treatment of predominantly moderate acne with or without concomitant medication results from the non-interventional cohort study ELANG. $J$ Eur Acad Dermatol Venereol. 2015;29(Suppl 4):15-22.

7. Gieler U, Gieler T, Kupfer JP. Acne and quality of life-impact and management. J Eur Acad Dermatol Venereol. 2015;29(Suppl 4):12-14.

8. Halvorsen JA, Stern RS, Dalgard F, Thoresen M, Bjertness E, Lien L. Suicidal ideation, mental health problems, and social impairment are increased in adolescents with acne: a population-based study. $J$ Invest Dermatol. 2011;131(2):363-370.

9. Gollnick HP, Finlay AY, Shear N. Global Alliance to Improve Outcomes in Acne. Can we define acne as a chronic disease? If so, how and when? Am J Clin Dermatol. 2008;9(5):279-284.

10. Collier CN, Harper JC, Cafardi JA, et al. The prevalence of acne in adults 20 years and older. $J$ Am Acad Dermatol. 2008;58(1):56-59.

11. Dréno B, Thiboutot D, Gollnick H, et al. Large-scale worldwide observational study of adherence with acne therapy. Int J Dermatol. 2010; 49(4):448-456.

12. Thiboutot $\mathrm{D}$, Gollnick $\mathrm{H}$, Bettoli $\mathrm{V}$, et al. New insights into the management of acne: an update from the Global Alliance to Improve Outcomes in Acne group. J Am Acad Dermatol. 2009;60(5 Suppl):S1-S50.

13. Poulin Y, Sanchez NP, Bucko A, et al. A 6-month maintenance therapy with adapalene-benzoyl peroxide gel prevents relapse and continuously improves efficacy among patients with severe acne vulgaris: results of a randomized controlled trial. Br J Dermatol. 2011;164(6): 1376-1382.

14. Nast A, Dréno B, Bettoli V, et al. European evidence-based (S3) guidelines for the treatment of acne - update 2016 - short version. J Eur Acad Dermatol Venereol. 2016;30:1261-1268.

15. Baldwin HE. Tricks for improving compliance with acne therapy. Dermatol Ther. 2006;19(4):224-236.
16. Gollnick HP, Bettoli V, Lambert J, et al. A consensus-based practical and daily guide for the treatment of acne patients. J Eur Acad Dermatol Venereol. Epub May 14, 2016.

17. Zaenglein AL, Pathy AL, Schlosser BJ, et al. Guidelines of care for the management of acne vulgaris. J Am Acad Dermatol. 2016;74(5): 945-973.e33.

18. Czernielewski J, Michel S, Bouclier M, Baker M, Hensby JC. Adapalene biochemistry and the evolution of a new topical retinoid for treatment of acne. J Eur Acad Dermatol Venereol. 2001;15(Suppl 3):5-12.

19. Dréno B, Bettoli V, Ochsendorf F, et al. Efficacy and safety of clindamycin phosphate $1.2 \%$ /tretinoin $0.025 \%$ formulation for the treatment of acne vulgaris: pooled analysis of data from three randomised, double-blind, parallel-group, phase III studies. Eur J Dermatol. 2014;24(2):201-209.

20. Leyden JJ, Hickman JG, Jarratt MT, Stewart DM, Levy SF. The efficacy and safety of a combination benzoyl peroxide/clindamycin topical gel compared with benzoyl peroxide alone and a benzoyl peroxide/erythromycin combination product. J Cutan Med Surg. 2001;5(1):37-42.

21. Schaller M, Sebastian M, Ress C, Seidel D, Hennig M. A multicentre, randomized, single-blind, parallel-group study comparing the efficacy and tolerability of benzoyl peroxide $3 \%$ /clindamycin $1 \%$ with azelaic acid $20 \%$ in the topical treatment of mild-to-moderate acne vulgaris. J Eur Acad Dermatol Venereol. 2016;30(6):966-973.

22. Leyden JJ. Current issues in antimicrobial therapy for the treatment of acne. J Eur Acad Dermatol Venereol. 2001;15(Suppl 3):51-55.

23. Suh DH, Kwon HH. What's new in the physiopathology of acne? Br J Dermatol. 2015;172(Suppl 1):13-19.

24. Graham GM, Farrar MD, Cruse-Sawyer JE, Holland KT, Ingham E. Proinflammatory cytokine production by human keratinocytes stimulated with Propionibacterium acnes and P. acnes GroEL. Br J Dermatol. 2004;150(3):421-428.

25. Ochsendorf F. [Systemic antibiotic therapy of acne vulgaris]. $J$ Dtsch Dermatol Ges. 2010;8(Suppl 1):S31-S46. German.

26. Dréno B. Bacteriological resistance in acne: a call to action. Eur $J$ Dermatol. 2016;26(2):127-132.

27. Walsh TR, Efthimiou J, Dréno B. Systematic review of antibiotic resistance in acne: an increasing topical and oral threat. Lancet Infect Dis. 2016;16(3):e23-e33.

28. Thiboutot DM, Weiss J, Bucko A, et al. Adapalene-benzoyl peroxide, a fixed-dose combination for the treatment of acne vulgaris: results of a multicenter, randomized double-blind, controlled study. J Am Acad Dermatol. 2007;57(5):791-799.

29. Haider A, Shaw JC. Treatment of acne vulgaris. JAMA. 2004;292(6): 726-735.

30. Tenaud I, Khammari A, Dreno B. In vitro modulation of TLR-2, CD1d, and IL-10 by adapalene on normal human skin and acne inflammatory lesions. Exp Dermatol. 2007;16(6):500-506.

31. Pariser DM, Westmoreland P, Morris A, Gold MH, Liu Y, Graeber M. Long-term safety and efficacy of a unique fixed-dose combination gel of adapalene $0.1 \%$ and benzoyl peroxide $2.5 \%$ for the treatment of acne vulgaris. J Drugs Dermatol. 2007;6(9):899-905.

32. Sardana K, Gupta T, Kumar B, Gautam HK, Garg VK. Cross-sectional pilot study of antibiotic resistance in Propionibacterium Acnes strains in Indian acne patients using 16S-RNA polymerase chain reaction: a comparison among treatment modalities including antibiotics, benzoyl peroxide, and isotretinoin. Indian J Dermatol. 2016;61(1):45-52.

33. Okamoto K, Ikeda F, Kanayama S, et al. In vitro antimicrobial activity of benzoyl peroxide against Propionibacterium acnes assessed by a novel susceptibility testing method. J Infect Chemother. 2016;22(6): 426-429.

34. Zeichner JA, Bhatt V, Pillai R. In vitro percutaneous absorption of benzoyl peroxide from three fixed combination acne formulations. J Clin Aesthetic Dermatol. 2013;6(8):19-22.

35. Bucks D, Sarpotdar P, Yu K, Angel A, Del Rosso J. The development and optimization of a fixed combination of clindamycin and benzoyl peroxide aqueous gel. J Drugs Dermatol. 2009;8(7):634-638. 
36. Gollnick H, Cunliffe W, Berson D, et al. Management of acne: a report from a Global Alliance to Improve Outcomes in Acne. $J$ Am Acad Dermatol. 2003;49(1 Supp1):S1-S37.

37. Eichenfield LE, Jorizzo JL, Dirschka T, et al. Treatment of 2,453 acne vulgaris patients aged 12-17 years with the fixed-dose adapalenebenzoyl peroxide combination topical gel: efficacy and safety. J Drugs Dermatol. 2010;9(11):1395-1401.

38. Tan J, Gollnick HP, Loesche C, Ma YM, Gold LS. Synergistic efficacy of adapalene $0.1 \%$-benzoyl peroxide $2.5 \%$ in the treatment of 3,855 acne vulgaris patients. J Dermatol Treat. 2011;22(4):197-205.

39. Eichenfield LF, Draelos Z, Lucky AW, et al. Preadolescent moderate acne vulgaris: a randomized trial of the efficacy and safety of topical adapalene-benzoyl peroxides. J Drugs Dermatol. 2013;12(6):611-618.

40. Bettoli V, Borghi A, Zauli S, et al. Maintenance therapy for acne vulgaris: efficacy of a 12-month treatment with adapalene-benzoyl peroxide after oral isotretinoin and a review of the literature. Dermatology. 2013; 227(2):97-102.

41. Gold LS, Cruz A, Eichenfield L, et al. Effective and safe combination therapy for severe acne vulgaris: a randomized, vehicle-controlled, double-blind study of adapalene $0.1 \%$-benzoyl peroxide $2.5 \%$ fixeddose combination gel with doxycycline hyclate $100 \mathrm{mg}$. Cutis. 2010; 85(2):94-104

42. Friedman A, Waite K, Brandt S, Meckfessel MH. Accelerated onset of action and increased tolerability in treating acne with a fixed-dose combination gel. J Drugs Dermatol. 2016;15(2):231-236.

43. Gollnick HP, Friedrich M, Peschen M, et al. Effect of adapalene $0.1 \%$ / benzoyl peroxide $2.5 \%$ topical gel on quality of life and treatment adherence during long-term application in patients with predominantly moderate acne with or without concomitant medication - additional results from the non-interventional cohort study ELANG. J Eur Acad Dermatol Venereol. 2015;29(Suppl 4):23-29.

44. Rueda MJ. Acne subject preference for pump over tube for dispensing fixed-dose combination adapalene $0.1 \%$-benzoyl peroxide $2.5 \%$ gel. Dermatol Ther (Heidelb). 2014;4(1):61-70.

45. Kwon HH, Park SY, Yoon JY, Min S, Suh DH. Do tutorials on application method enhance adapalene-benzoyl peroxide combination gel tolerability in the treatment of acne? J Dermatol. 2015;42(11): 1058-1065.

46. Dréno B, Kaufmann R, Talarico S, et al. Combination therapy with adapalene-benzoyl peroxide and oral lymecycline in the treatment of moderate to severe acne vulgaris: a multicentre, randomized, doubleblind controlled study. Br J Dermatol. 2011;165(2):383-390.
47. Anderson KL, Dothard EH, Huang KE, Feldman SR. Frequency of primary nonadherence to acne treatment. JAMA Dermatol. 2015;151(6): 623-626.

48. Tanghetti EA. The noncompliant patient with acne. Skin Therapy Lett. 2011;16(10):4-5.

49. Yentzer BA, Gosnell AL, Clark AR, et al. A randomized controlled pilot study of strategies to increase adherence in teenagers with acne vulgaris. J Am Acad Dermatol. 2011;64(4):793-795.

50. Gold LS, Tan J, Cruz-Santana A, et al; Adapalene-BPO Study Group. A North American study of adapalene-benzoyl peroxide combination gel in the treatment of acne. Cutis. 2009;84(2):110-116.

51. Gollnick HP, Draelos Z, Glenn MJ, et al; Adapalene-BPO Study Group. Adapalene-benzoyl peroxide, a unique fixed-dose combination topical gel for the treatment of acne vulgaris: a transatlantic, randomized, double-blind, controlled study in 1670 patients. $\mathrm{Br} J$ Dermatol. 2009;161(5):1180-1189.

52. Zouboulis CC, Fischer TC, Wohlrab J, Barnard J, Alió AB. Study of the efficacy, tolerability, and safety of 2 fixed-dose combination gels in the management of acne vulgaris. Cutis. 2009;84(4):223-229.

53. Gonzalez P, Vila R, Cirigliano M. The tolerability profile of clindamycin $1 \%$ /benzoyl peroxide $5 \%$ gel vs. adapalene $0.1 \%$ /benzoyl peroxide $2.5 \%$ gel for facial acne: results of a randomized, single-blind, split-face study. Cosmet Dermatol. 2012;11(4):251-260.

54. Tan J, Humphrey S, Vender R, et al; POWER study group. A treatment for severe nodular acne: a randomized investigator-blinded, controlled, noninferiority trial comparing fixed-dose adapalene/ benzoyl peroxide plus doxycycline vs. oral isotretinoin. Br J Dermatol. 2014;171(6):1508-1516.

55. Loesche C, Pernin C, Poncet M. Adapalene $0.1 \%$ and benzoyl peroxide $2.5 \%$ as a fixed-dose combination gel is as well tolerated as the individual components alone in terms of cumulative irritancy. Eur $J$ Dermatol. 2008;18(5):524-526.

56. Green L, Cirigliano M, Gwazdauskas JA, Gonzalez P. The Tolerability Profile of Clindamycin 1\%/Benzoyl Peroxide 5\% Gel vs. Adapalene $0.1 \%$ /Benzoyl Peroxide $2.5 \%$ Gel for Facial Acne: Results of Two Randomized, Single-Blind, Split-Face Studies. J Clin Aesthet Dermatol. 2012;5(5):16-24.

57. Sittart JA, Costa AD, Mulinari-Brenner F, Follador I, Azulay-Abulafia L, Castro LC. Multicenter study for efficacy and safety evaluation of a fixeddose combination gel with adapalen $0.1 \%$ and benzoyl peroxide $2.5 \%$ (Epiduo ${ }^{\circledR}$ for the treatment of acne vulgaris in Brazilian population. An Bras Dermatol. 2015;90(6 Suppl 1):1-16.
Therapeutics and Clinical Risk Management

\section{Publish your work in this journal}

Therapeutics and Clinical Risk Management is an international, peerreviewed journal of clinical therapeutics and risk management, focusing on concise rapid reporting of clinical studies in all therapeutic areas, outcomes, safety, and programs for the effective, safe, and sustained use of medicines. This journal is indexed on PubMed Central, CAS,

\section{Dovepress}

EMBase, Scopus and the Elsevier Bibliographic databases. The manuscript management system is completely online and includes a very quick and fair peer-review system, which is all easy to use. Visit http://www.dovepress.com/testimonials.php to read real quotes from published authors. 